\title{
Incidences of Rabies in Domestic Animals and Consequent Risk Factors in Humans
}

Tekki IS ${ }^{* 1}$, Meseko $\mathrm{CA}^{1}$, Omotainse $\mathrm{SO}^{2}$, Atuman $\mathrm{YJ}^{1}$, Chukwukere ${ }^{1}$, Olaleye $\mathbf{S}^{1}$ and Okewole $\mathrm{PA}^{1}$

${ }^{1}$ National Veterinary Research Institute, Plateau State, Nigeria

2 University of Agriculture Abeokuta, Ogun State, Nigeria

“Corresponding author: Ishaya Sini Tekki, National Veterinary Research Institute, Vom, Plateau State, Nigeria, Tel: 2348036012637; E-mail: sini.tekki@nvri.gov.ng, ishaya.sinitekki@yahoo.com

Rec Date: Dec 24, 2013, Acc date: June 27, 2014, Pub date: June 30, 2014

Copyright: (c) 2014 Tekki IS, et al. This is an open-access article distributed under the terms of the Creative Commons Attribution License, which permits unrestricted use, distribution, and reproduction in any medium, provided the original author and source are credited.

\begin{abstract}
Although rabies infects all warm blooded animals in nature, the primary hosts are domestic and wild dogs. Many other susceptible hosts include cats, foxes, and bats many of which also serve as reservoir and source of infection to other animals including human and livestock. Incidence of rabies in livestock is a re-emerging global phenomenon being reported in both rabies endemic and hitherto dog rabies free countries. We report cases of rabies in cattle, sheep and goat in Nigeria, highlighting the risk factors of human exposure due to handling and consumption the carcases. The food animals exposed to rabies exhibited the clinical signs including hyperactivities, aggression and drooling of saliva and were confirmed positive for rabies by Fluorescent antibody test. This implies that excess dog rabies goes into atypical hosts like these food animals. Though these animals are dead-end hosts, the consequence is that more human exposure, through these atypical means, is possible by direct bites, contact with saliva or other body fluids from slaughter and consumption of these animals. Control of rabies in domestic dogs and vaccination of other live stocks like cows, sheep and goats, is necessary to prevent untold economic loses and risks of humans exposure to rabies.
\end{abstract}

Keywords: Rabies; Incidence; Risk; Exposure; Domestic animals; Nigeria

\section{Introduction}

Rabies is a rapidly progressive and uniformly fatal viral meningoencephalitis caused by the bullet-shaped viral particles of the rabies group of Rhabdoviridae, genus Lyssavirus [1]. Although rabies virus infects all warm blooded animals in nature, the primary hosts are domestic and wild dogs [2,3]. Many other susceptible hosts include cats, foxes, and bats many of which also serve as reservoir hosts and source of infection to humans and other animals including livestock $[3,4]$. In developing countries of Africa and Asia, exposures to rabies virus are mainly through bites from rabid dogs and these accounts for over $90 \%$ of confirmed rabies cases $[5,6]$.

The epizootiology of rabies has been previously described in Nigeria [7-10], with dogs incriminated as the predominant reservoir of the disease.

\section{Case Reports}

\section{Case I}

On September 04, 2012, brain specimen of adult male 'Yankasa' breed of sheep was brought to the NVRI laboratory in Bauchi, Bauchi state, Nigeria, from a Local Government area in Gombe State, Nigeria, requesting for rabies diagnosis. Case history revealed that one out of a flock of 5 Yankasa breed of sheep on semi-intensive system of management was reported to manifest abnormal behaviours including: attacking people and other animals in the flock that approached it. The owner separated the sick animal from the rest and it died few days after the unset of the disease. The owner could not tell whether or not the animal was previously bitten by a dog, cat or any other animal.

\section{Case II}

Similarly, brain tissue of 'White Fulani' adult female cattle was presented to the same laboratory as in case I above on September 26, 2012, from a Veterinary Clinic in Bauchi, Nigeria, for rabies diagnosis. History of the case showed that a stray dog entered a herd of more than 50 cattle on extensive range and bit 5 of the animals. About 7 weeks after exposure, all the 5 cattle bitten by the dog began to exhibit abnormal nervous signs which include: salivation, restlessness and aggression to the rest of the animals on the farm. One of the affected animals was slaughtered and the head presented the next day for rabies diagnosis, while the rest of the exposed animals were sold.

\section{Case III}

On November 15, 2012, brain specimen from adult female 'West African Dwarf breed of goat was submitted to the National Veterinary Research Institute (NVRI), Vom for rabies diagnosis, from Abeokuta, Ogun state, Nigeria. The animal was said to have exhibited nervous signs, such as: agitation/restlessness and aggression, leading to suspicion of rabies. When the animal died naturally few days later, the head was severed, brain harvested and submitted for confirmatory diagnosis of rabies.

\section{Laboratory Diagnosis}

After necessary documentations, impression smears of the brain specimens (hippocampus, cerebellum, brain stem and the thalamus) 
Citation: Tekki IS, Meseko CA, Omotainse SO, Atuman YJ, Chukwukere, Olaleye S, et al. (2014) Incidences of Rabies in Domestic Animals and Consequent Risk Factors in Humans. J Med Microb Diagn 3: 143. doi:10.4172/2161-0703.1000143

Page 2 of 3

were made on pre-cleaned glass slides and fixed in chilled analytical grade acetone.

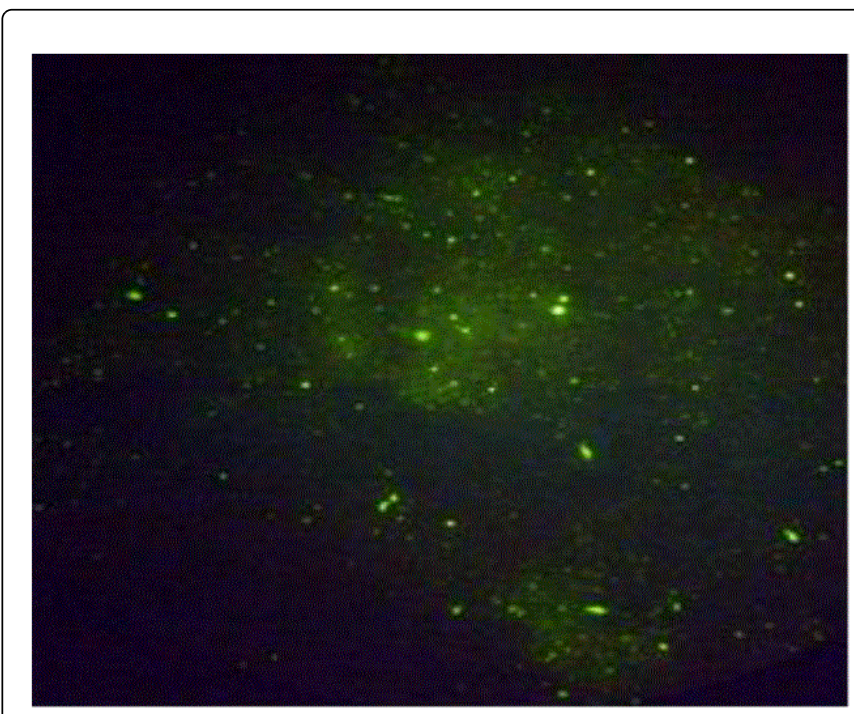

Figure 1: positive slide from Case I showing immunofluorescence

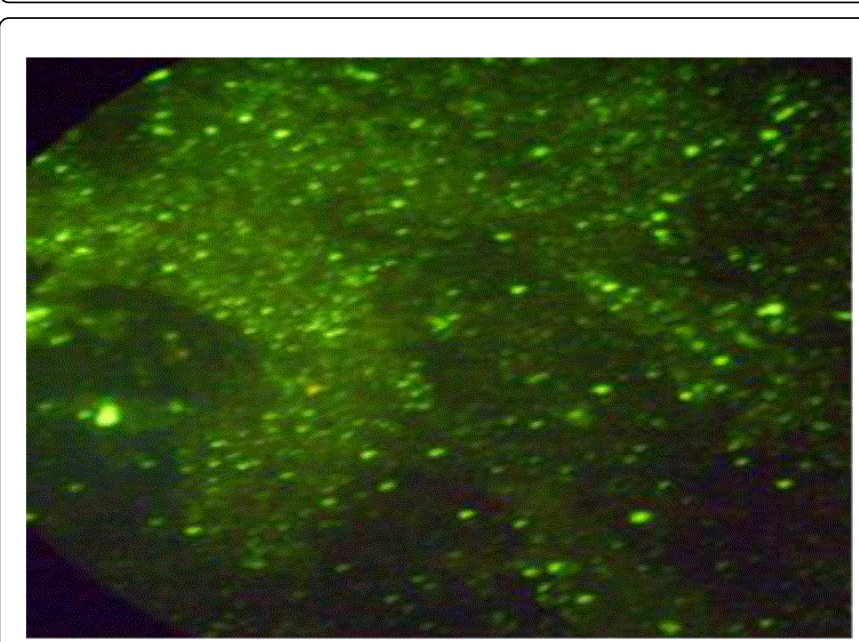

Figure 2: positive slide from Case II showing immunofluorescence

Smears were stained with rabies antinucleocapsid (conjugate N4-13) Fluorescein Isothiocyanate Conjugate obtained from ARCOnderstepoort Veterinary Institute, Private Bag X05, Onderstepoort 0110, South Africa, according to manufacturer's instructions; for rabies virus antigen detection by direct fluorescent antibody test (dFAT) as described by [11] (though with slight modifications). These modifications include: fixation of smears in acetone for 15 minutes instead of 4 hours and staining of smears with 1:1000 working dilution of conjugate instead of 1:5). Positive and negative control smears were made from brain tissue of rabies-positive infected and rabies-negative non-infected baby mice respectively. All slides were carefully examined using Fluorescence Microscope (Axioskop G/115-230), royal blue LED $(455 \mathrm{~nm})$ excitation with X10 eyepiece and X20 objective, comparing the test slides with the positive and negative controls.

\section{Results}

In all the cases, rabies virus antigen was detected by N4-15 fluorescein-conjugated antibodies specific for lyssaviruses as shown in Figures 1-3 compared to the negative control (Figure 4).

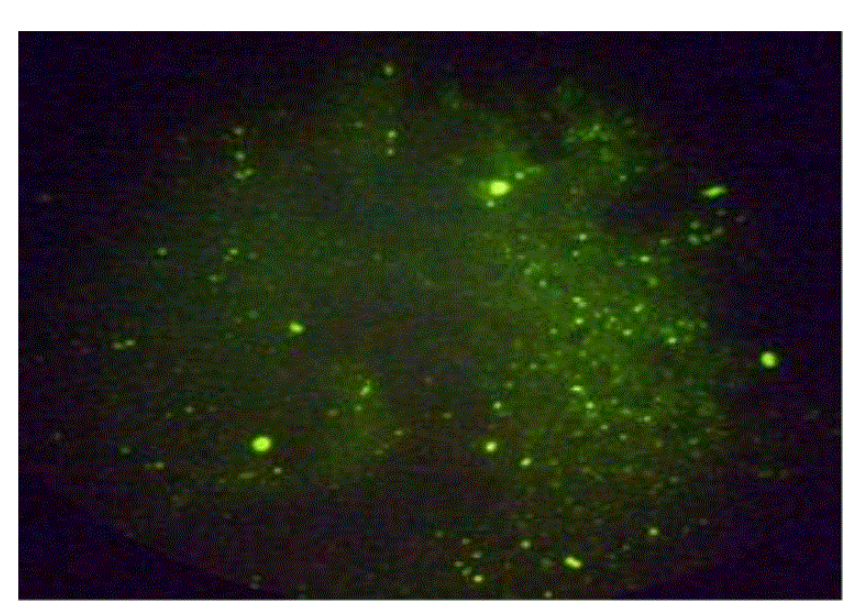

Figure 3: positive slide from Case III showing immunofluorescence

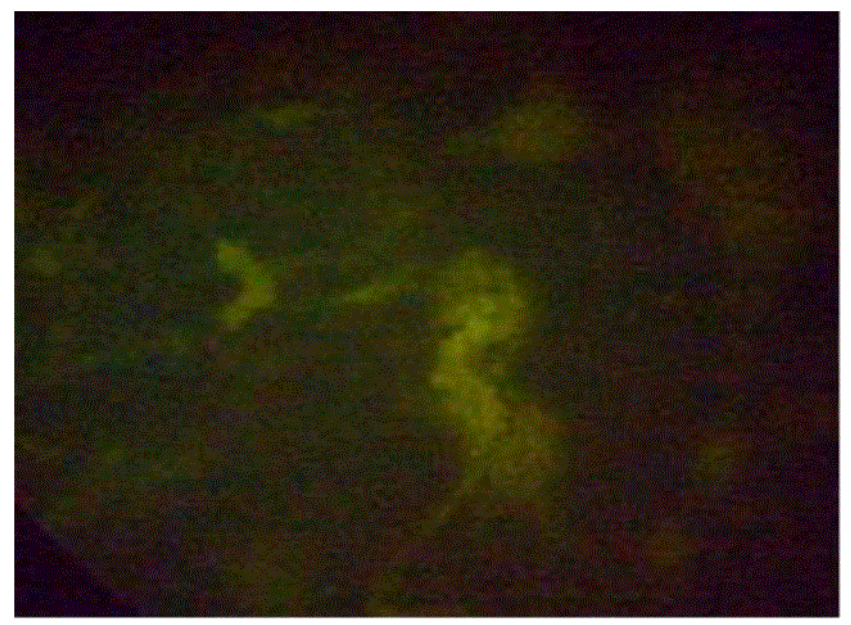

Figure 4: Negative control slide showing no immunofluorescence

\section{Discussion}

These results imply that dog rabies is in surplus in the regions where these cases occurred to have gone into atypical hosts such as food animals (cattle, sheep and goat in Bauchi, Gombe and Abeokuta respectively). Incidence of rabies in livestock is a re-emerging global phenomenon being reported in rabies endemic and hitherto dog rabies free countries [12]. Vampire bats also transmitted paralytic rabies in cattle in 7 regions of Mexico in 2012 [12]. Similar situation, in the USA was reported in cattle [12].

Although, [13] put domestic animal death due to rabies at 1, 000 per annum in Nigeria in the late 1970s, the current death rate would certainly be much higher with continuous increase of rabies cases in all 
the regions of the country. In the same vein, even though livestock animals are dead-end hosts of rabies, there seems to be increased risk of human exposure by direct contamination with saliva, tissues and other body fluids during handling, slaughter, processing and consumption of the parts and products of these animals. Reports from the field showed that carcasses of the animals in Case I and III were sold in local markets and must have been consumed by humans who were unaware of the circumstances. There is therefore need for public education on the dangers of consumption of sick animals which could be source of transmission of zoonotic diseases to humans

Whereas recent reports [14], have described atypical rabies exposure as gradually gaining prominence globally, little is known about atypical rabies exposure of humans from domestic animals in Nigeria. This may be due to underreporting of the disease in animals and humans $[5,15,16]$. However, available records show that atypical rabies exposure is most likely among consumers of dog meat as well as dog handlers trading in dogs at live-dog markets. Slaughtering and consumption of dog meat is a common practice in many parts of Nigeria [5]. Over the years, the risk of exposure to rabies in such dog handlers, traders and consumers is largely underestimated and in most cases taken for granted. Consequently, persons dying mysteriously are associated with attack by witches and wizards. In most cases, people concerned are uneducated rural poor who are oblivious of the risks involved [17].

In addition to its public health significance, the economic importance of rabies is related to its occurrence in domestic animals (especially cattle, sheep and goat) which are source of food and money to the rural poor. If left uncontrolled, rabies in domestic animals will lead to such a great economic loses as any sick animal has little or no market value. Decreased milk production is another cardinal adverse effect of diseases including rabies on dairy cattle which translates to huge economic losses to the farmers specifically and to the livestock subsector. To avoid these menaces, disease surveillance should be an integral part and key component of government veterinary services for the purpose of defining animal health status, detect changes in health status-eradication or absence of disease, and to enable action-plan for early disease warning and emergency preparedness.

Surveillance is also important for planning and monitoring of disease control program, provision of sound animal health advice to farmers, and certification of export livestock and livestock products. It is based on a continuous inspection and control implementation at risk locations like livestock markets, slaughter facilities, control posts, grazing reserves, and wildlife packs. On the other hand, lack of surveillance data on emerging zoonoses from many developing countries means that the burden of human, livestock and, wildlife disease is underestimated and opportunities for control interventions thereby limited [18].

Dog vaccination still remains a cost effective option for rabies control especially since post exposure prophylaxis in humans is much more expensive and the current economic situations in developing countries may not guarantee access to the full course of regimen. Similarly, vaccination of livestock animal in affected areas should be considered as was the case in Bela Vista city, Arkansas state, USA, where rabies outbreak was encountered, more than 200 cattle were vaccinated in 2012 with 2 doses of the vaccine applied in order to guarantee the prevention of the disease in bovine, equine, goat, and sheep [12]. All stakeholders in the livestock industry which comprise: livestock owners, concerned authorities at the 3 tiers of government, other health agency, and veterinarians both in public and private services need to work in coordination for the control of this disease to forestall its spread among animal and human populations. In conclusion, although the risk of acquiring rabies virus infection through eating meat from infected animals is negligible, it is never prudent to consume tissue from ill or dead animals. It is also necessary to maintain distance from ill or rabid animals.

\section{References}

1. Fenner FJ, Gibbs E, Paul J, Murphy FA, Rudolf, et al. (1993) Micheal, Studdert J, White. Veterinary Virology (2nd Ed).

2. Centers for Disease Control (CDC) (1987) An imported case of rabies in an immunized dog. MMWR Morb Mortal Wkly Rep 36: 94-96.

3. Bingham J (2005) Canine rabies ecology in southern Africa. Emerg Infect Dis 11: 1337-1342.

4. Ogunkoya AB (1997). Rabies: Basic Concept, Problems and Prospects of its Control in Nigeria. Oreofe Nigeria Limited Publishers, Akure, Nigeria.

5. Coker AO, Isokpehi RD, Thomas BN, Fagbenro-Beyioku AF, Omilabu SA (2000) Zoonotic infections in Nigeria: overview from a medical perspective. Acta Trop 76: 59-63.

6. WHO (2012). WHO Expert Consultation on Rabies. WHO Technical Report Series WHO Technical Report Series 982.

7. Boulger LR, Hardy J (1960) Rabies in Nigeria. W. African Med. J. 9: 223-234

8. Umoh JU, Belino ED (1979) Rabies in Nigeria. A historical review. Int J Zoonoses 6: 41-48.

9. Ogunkoya AB (1986). Epidemiology of rabies in Kaduna, Oyo and Lagos States of Nigeria. M.Sc. Thesis, Ahmadu Bello University, Zaria

10. Awoyomi OJ, Adeyemi IG, Awoyomi FS, (2007). Socioeconomic Factors Associated with Non- Vaccination of Dogs against Rabies in Ibadan, Nigeria. Nigerian Veterinary Journal; 28: 59-63

11. Goldwasser Ra, Kissling Re, Carski Tr, Hosty Ts (1959) Fluorescent antibody staining of rabies virus antigens in the salivary glands of rabid animals. Bull World Health Organ 20: 579-588.

12. ProMED (2012). Public Hlth. Assoc., Washington, D.C: 273-279.

13. Nawathe D R (1980). Rabies Control in Nigeria. Bull. Off. int. Epiz.; 92: 129-139.

14. Wertheim HF, Nguyen TQ, Nguyen KA, de Jong MD, Taylor WR, et al. (2009) Furious rabies after an atypical exposure. PLoS Med 6: e44.

15. Opaleye OO, Adesiji YO, Olowe OA, Fagbami AH (2006) Rabies and antirabies immunization in South Western Nigeria: knowledge, attitude and practice. Trop Doct 36: 116-117.

16. El-Yuguda AD, Baba AA, Baba SSA. Dog Population Structure and Cases of Rabies among Dog Bite Victims in Urban and Rural areas of Borno State, Nigeria. Trop. Vet.; 25: 34-40.

17. Meseko CA, Tekki SI, Ifende VI, Bala A, Muhammad LU, et al. (2013 - in Press). Dog Meat, Rabies, Animal Welfare and Legislation.

18. Merianos A (2007) Surveillance and response to disease emergence. Curr Top Microbiol Immunol 315: 477-509. 